\title{
AN ECONOMETRIC ASSESSMENT OF T.R. MALTHUSIAN THEORY OF POPULATION: EMPIRICAL EVIDENCE IN INDIA
}

\author{
Dr. K. SUBRAMANIAN
}

Assistant Professor, Post Graduate and Research, Department of Economics,

Saraswathi Narayanan College, Madurai, Tamil Nadu, India

\begin{abstract}
T. R. Malthus propounded a theory of the relationship between population growth and economic development. He wrote an essay in 1798 on “The Principles of Population'. He said that population increases in geometric ratio (i.e., 10, 20, 40, 80...) whereas, the food supply increases only in arithmetic ratio (i.e., 10, 20, 30, 40...). He stated that 'nature will restore the equilibrium, if man fails to check his own growth'.
\end{abstract}

KEYWORDS: Geometric Ratio, Arithmetic Ratio, Positive Checks\& Preventive Checks

Received: May 01, 2020; Accepted: May 22, 2020; Published: Jun 05, 2020; Paper Id.: IJECRJUN202015

\section{INTRODUCTION}

In ancient times, several statesmen and thinkers applied their minds to the questions of the desirable size of population and the need for either encouraging or discouraging population growth.In recent years, economists, noneconomists and demographers have begun to focus increasingly on the relationship between economic development and population growth.World population growth accelerated drastically between the Second World war and 1950 to one per cent a year, and following that to an unprecedented two per cent. The effect was to nearly double World population between 1950 and today.

\section{MALTHUSIAN THEORY AND ITS RELEVANCE IN INDIA}

Almost 220 years ago, the reverend Thomas R Malthus postulated his theory on the relationship between population growth and economic development. In his Essay on the Principle of Population, (1798), Malthus noted a universal tendency for the population of a country, unless checked by dwindling food supplies, to grow at a geometric ratio doubling every 25 years. At the same time, food supplies could only expand roughly at an arithmetic ratio, because of diminishing returns to the fixed factor-land. As each member of the population would have less land with which to work, his marginal contribution to food production would decline. Because, the growth in food supplies could not keep pace with the rapid growth of population, per capita food production would have a tendency to fall, leaving a stable population existing barely at or slightly above the subsistence level.Malthus contended that the only way to avoid this condition of a chronic low standard of living, or "Absolute Poverty" was for people to engage in "moral restraint' and limit the members of their progeny. In the absence of such preventive checks, "Positive" checks (starvation, disease, wars etc.) on population growth would inevitably provide the restraining force.Thus, poor nations would never be able to rise much above their subsistence level of per capita income unless they initiated Neo-Malthusian "Preventive Checks" i.e., birth control on their population growth. From this viewpoint, although Malthus was against birth control for religious reasons, one may regard him as the father of the modern birth control 
movement. As discussed, most of Malthus's predictions were proved incorrect in developed nations, as population growth rates slowed and rates of food grain production were very high due to improved farm technology. However, in most of the developing nations his predictions have been found correct.These countries are characterized by high growth rate of population, relatively low rates of food grains production and progressive impoverishment of a sizable section of the people. According to some economists, India is also no exception. This view is supported by the fact that the land supply is virtually fixed and already a high population land ratio exists.At the other extreme, it is argued that there is still great potential for increasing food grain production through increasing irrigation facilities and applying modern technology. Moreover, present per acre yield is very low, conditions are favourable, soil is very fertile and sufficient volumes of water, including sub-soil water is available. Hence these writers claim Malthus's predictions do not hold good even for the developing nations.

\section{The "Qualified" Malthusian Doctrine}

There were three important qualifications finally, which distinguish the Malthusian doctrine from a strict historical prophecy or forecast.

\section{Rate of Growth of Population}

According to Malthus, the population increases in geometrical progression i.e., in the ratio1,2,4,8, 16,32,64,128,256 etc.

\section{The Rate of Growth Means of Subsistence}

According to Malthus, the means of subsistence increase only in arithmetical progression, i.e., in the ration of $1,2,3,4,5,6,7,8,9$ and so on.

Every term corresponds to a period of twenty-five years, and a glance at the figures will show us that population supposed to double every twenty-five years, while the means of substance merely increases by an equal amount during each of these periods. Thus the divergence between the two series grows with astonishing rapidity.

\section{The Checks to Population}

The increase in geometrical ratio of population and arithmetical ratioof the means of subsistence tends to disturb the balance between the population and the food supply. Malthus exhorts mankind to practice preventive checks in order to escape the wrath of nature. The Malthusian theory of population can be explained by means of simple chart thus. 


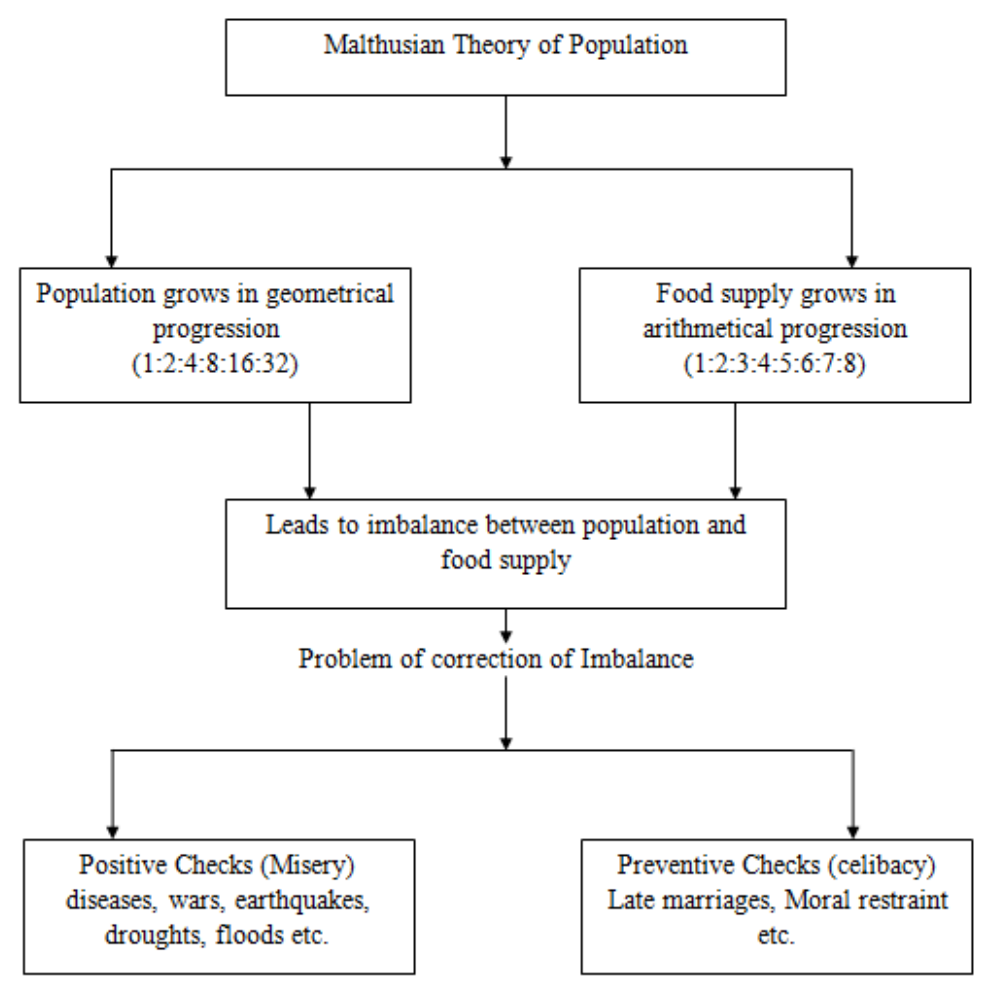

\section{RESEARCH OBJECTIVES}

Figure 1

The study has been guided by the following objectives

- $\quad$ To analyse the trends in the growth of population and food supply in India.

- The applicability of Thomas Robert Malthus view in the Indian Scenario with regard to population growth and food supply.

\section{Hypothesis}

H1: An increase in population growth will decrease agricultural production.

\section{REVIEW OF RELEVANT LITERATURE}

In the words of Das M.M and Datta L (2006),it is a dismal fact that all the seven States of North East India has been suffering all along from food deficiency, as the food grains production has not been adequate because of the practice of traditional methods of cultivation, in spite of the fact that there has been enough potential of abundant food grains production. On the other hand, there has been tremendous growth of population, which has increased the demand of food to an unmanageable proportion. As a result, these States have to rely on imported food, which has found to be not sufficient and reliable making thereby the poor people vulnerable to food insecurity, not to speak of getting nutrition. As they do not have purchasing power, they cannot depend on food commodities available in the free markets. They have, therefore, to depend on the food supplied through the Public Distribution System (PDS) at subsidized price. But the Government's recent policy to reduce the subsidy to the food supplied through the PDS and to limit the number of beneficiaries only to those who fall below the poverty line, a large section of the people belonging to the small and marginal farmers in the States of the North East India, become the victims of food insecurity, malnutrition and under 
nutrition. Therefore, the only alternative is to increase the production and productivity of food grains within the region itself through modern sustainable methods in order to make the people self-sufficient in food production, in which, there is enough potential in some areas of the region not yet realized to an optimum level. The empirical study reveals that there is still a big gap between the potential and the actual production of food grains at least in the biggest State of Assam with plenty of fertile alluvial plains. If the potential of Assam alone could be fully utilized by providing irrigation only, it could feed the entire North East India besides fulfilling its own needs. Emphasis should, therefore, be given on development of agriculture in the region for satisfying the need of the ever increasing population. As the explosive growth of population is not the result of natural birth rate alone, but of large-scale immigration from the neighbouring foreign countries and other States of India, strict measures should be taken to control immigration. Otherwise scarcity in the region will be a never ending phenomenon.

\section{RESEARCH METHODOLOGY AND DATABASE}

Materials and methods in this study covers study period, sources of data, tools used and analysis methodology.

\section{Reference Period}

The study covers a period of fifty seven (57) years. Decade-wise analysis has been followed in the study from 1960-1961 to $1969-1970,1970-1971$ to $1979-1980,1980-1981$ to $1989-1990,1990-91$ to $1999-2000,2000-2001$ to $2009-2010$ and 2010-2011 to 2017-2018.

\section{Sources of Data}

The study is based on secondary data, since it requires aggregate time series data over a period of time. The secondary data have been obtained from various published and unpublished sources.

\section{National Sources}

The information required for the study have been collected from Reserve Bank of India Handbook of Statistics on Indian Economy, Economic Survey, Statistical Office records, Annual reports available in Government and Non-Government websites, various Indian Economy and Econometrics books, articles published in journals like Economic and Political Weekly, Indian Streams Research Journal, Southern Economist, Indian Economic Journal, Third Concept.

\section{International Sources}

The information required for the study have also been collected from various articles published in the International Journal of Economics and Management Sciences, International Review of Applied Economic Research, The Journal of World Economic Review and Asian African Journal of Economics and Econometrics.

\section{Data Analysis and Tools used}

The collected data have been processed both manually and with the help of computer software systems, Microsoft Excel and Statistical Package for Social Sciences (SPSS). The following appropriate statistical tools have been used in this study.

\section{Trend Analysis}

The objective of the present study is to analyse the growth of population and food supply in India. For this purpose, two popular forms of trend analysis, namely the linear trend model and the semi-log model have been used. 
To fit the straight line, a model of the following type has been used

$\mathrm{T}=\mathrm{a}+\mathrm{b}_{\mathrm{t}}+\mathrm{U}_{\mathrm{t}}$

$\mathrm{T}=$ Population in crore and food supply in million ton.

"a" is the constant to be estimated, " $b_{t}$ " is annual absolute growth in the variables.

" $t$ " denote the time in years. " $\mathrm{t}$ " has taken values for $1,2,3, \ldots$ " $\mathrm{U}_{\mathrm{t}}$ " is the disturbance term " $\mathrm{b}$ " is the regression co-efficient showing the annual growth or decline in the population and food supply in India. The compound growth rates have also been worked out for population and food supply growth for the six sub-decades and as also for the whole period.

To get the constant annual compound growth rate, another semi-log model of the following type has been used in this study.

This semi-log model is $\log y=a+b_{t}$

Compound growth rate $=[\operatorname{antilog}(b-1) 100]$

The above regression models are estimated using the principle of least square. The compound growth rates of the population and food supply are estimated for the six sub-decades $1960-61$ to $1969-1970,1970-71$ to $1979-80,1980-81$ to 1989-90, 1990-91 to $1999-2000,2000-01$ to 2009-10, 2010-11 to 2017-18 and also for the entire period of 1960-1961 to 2017-18.

\section{ANALYSIS AND DISCUSSIONS}

Table 1 shows the growth of food grain production and growth of population duringpre-reform period.

Table 1: Growth of Population and Food Grains during Pre-form Period

\begin{tabular}{|c|c|c|}
\hline Year & Population (in Crore) & Total Food Grains (Million Ton) \\
\hline $1960-61$ & 43.4 & 82.02 \\
\hline $1961-62$ & 44.4 & 82.71 \\
\hline $1962-63$ & 45.4 & 80.15 \\
\hline $1963-64$ & 46.4 & 80.64 \\
\hline $1964-65$ & 47.4 & 89.36 \\
\hline $1965-66$ & 48.5 & 72.35 \\
\hline $1966-67$ & 49.5 & 74.23 \\
\hline $1967-68$ & 50.6 & 95.05 \\
\hline $1968-69$ & 51.8 & 94.01 \\
\hline $1969-70$ & 52.9 & 99.50 \\
\hline $1970-71$ & 54.1 & 108.42 \\
\hline $1971-72$ & 55.4 & 105.42 \\
\hline $1972-73$ & 56.7 & 97.03 \\
\hline $1973-74$ & 58.0 & 104.67 \\
\hline $1974-75$ & 59.3 & 99.83 \\
\hline $1975-76$ & 60.7 & 121.03 \\
\hline $1976-77$ & 62.0 & 111.17 \\
\hline $1977-78$ & 63.4 & 126.41 \\
\hline $1978-79$ & 64.8 & 131.90 \\
\hline $1979-80$ & 66.4 & 109.70 \\
\hline $1980-81$ & 67.9 & 129.59 \\
\hline $1981-82$ & 69.2 & 133.30 \\
\hline $1982-83$ & 70.8 & 129.52 \\
\hline $1983-84$ & 72.3 & 152.37 \\
\hline & & \\
\hline
\end{tabular}




\begin{tabular}{|c|c|c|}
\hline $1984-85$ & 73.9 & 145.54 \\
\hline $1985-86$ & 75.5 & 150.44 \\
\hline 1986-87 & 77.1 & 143.42 \\
\hline $1987-88$ & 78.8 & 140.35 \\
\hline 1988-89 & 80.5 & 169.92 \\
\hline $1989-90$ & 82.2 & 171.04 \\
\hline 1990-91 & 83.9 & 176.39 \\
\hline 1991-92 & 85.6 & 168.38 \\
\hline $1992-93$ & 87.2 & 179.48 \\
\hline 1993-94 & 89.2 & 184.26 \\
\hline 1994-95 & 91.0 & 191.50 \\
\hline $1995-96$ & 92.8 & 180.42 \\
\hline 1996-97 & 94.6 & 199.43 \\
\hline 1997-98 & 96.4 & 193.12 \\
\hline $1998-99$ & 98.3 & 203.61 \\
\hline $1999-2000$ & 100.1 & 209.80 \\
\hline $2000-01$ & 101.9 & 196.81 \\
\hline 2001-02 & 104.0 & 212.85 \\
\hline 2002-03 & 105.6 & 174.78 \\
\hline 2003-04 & 107.2 & 213.19 \\
\hline 2004-05 & 108.9 & 198.36 \\
\hline 2005-06 & 110.6 & 208.60 \\
\hline 2006-07 & 112.2 & 217.28 \\
\hline 2007-08 & 113.8 & 230.78 \\
\hline 2008-09 & 115.4 & 234.47 \\
\hline 2009-10 & 117.0 & 218.11 \\
\hline $2010-11$ & 118.6 & 244.49 \\
\hline 2011-12 & 122.0 & 259.29 \\
\hline $2012-13$ & 123.5 & 257.13 \\
\hline 2013-14 & 125.1 & 265.04 \\
\hline 2014-15 & 126.7 & 252.02 \\
\hline $2015-16$ & 128.3 & 251.57 \\
\hline 2016-17 & 129.9 & 275.11 \\
\hline 2017-18 & 131.6 & 284.83 \\
\hline
\end{tabular}

Source: RBI Handbook of Statistics on Indian Economy, Various Issues.

Table 1 shows the growth of population and the growth of food grain production in India, since 1960-1961. The table shows that food grains production has increased from 82.02 million ton in the year 1960-1961 to 284.83 million ton in the year 2017-2018. The corresponding population growth in this period are 43.4 and 131.6 crore respectively.

Table 2: Growth of Population and Food Supply 1960-61 to 1969-70

\begin{tabular}{|c|c|c|c|c|c|c|c|c|c|}
\hline Period & Items & Model & $\mathbf{a}$ & b & Std-Error & T-Stab & Sig-t & $\mathbf{R}^{2}$ & CGR \\
\hline \multirow{4}{*}{$\begin{array}{c}1960-61 \text { to } \\
1969-70\end{array}$} & \multirow{2}{*}{ Population } & Linear & $\begin{array}{l}42.28 \\
0556\end{array}$ & $\begin{array}{l}1.04 \\
1667\end{array}$ & $\begin{array}{c}0.103 \\
19\end{array}$ & 100.947 & 0.0000 & $\begin{array}{l}0.99 \\
931\end{array}$ & 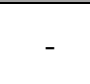 \\
\hline & & Log- Linear & $\begin{array}{c}3.749 \\
163 \\
\end{array}$ & $\begin{array}{c}0.219 \\
51 \\
\end{array}$ & 8.7486 & 250.906 & 0.000 & 0.99989 & 2.219 \\
\hline & \multirow{2}{*}{ Food Supply } & Linear & $\begin{array}{l}77.98 \\
6944 \\
\end{array}$ & $\begin{array}{c}1.080 \\
833 \\
\end{array}$ & $\begin{array}{c}1.0240 \\
85 \\
\end{array}$ & 1.055 & 0.3263 & $\begin{array}{l}0.13 \\
728 \\
\end{array}$ & - \\
\hline & & Log- Linear & $\begin{array}{c}4.361 \\
068 \\
\end{array}$ & $\begin{array}{c}0.011 \\
683 \\
\end{array}$ & $\begin{array}{c}0.0124 \\
10 \\
\end{array}$ & 0.941 & $\begin{array}{c}0.37 \\
78 \\
\end{array}$ & $\begin{array}{l}0.11 \\
238 \\
\end{array}$ & 1.175 \\
\hline
\end{tabular}

From Table 2, it is vivid clear that in the decade from 1960-61 to 1969-70, the population had grown at an absolute rate of 1.04 crore per annum, whereas the food supply had grown at an absolute rate of 1.08 million ton per year. The semi log model shows that the values of slope coefficient of population and food supply in the years 1960-61 to 1969- 
70 are 0.219 and 0.011 , which shows that the population and food supply had grown at the rate of 21.95 and 1.2 per cent. The regression estimates are statistically significant at 5 per cent and 1 per cent level. In the decade from 1960-61 to 196970 , the population and food supply had increased at a compound growth rate of 2.219 and 1.175 per cent, respectively. Thus, in the decade from 1960-61 to 1969-70, the growth of food supply is just over the growth of population.

Table 3: Growth of Population and Food Supply in the Decade from 1970-71 to 1979-80

\begin{tabular}{|c|c|c|c|c|c|c|c|c|c|}
\hline Period & Items & Model & $\mathbf{a}$ & b & Std-Error & T-Stab & Sig-t & $\mathbf{R}^{2}$ & CGR \\
\hline \multirow{4}{*}{$\begin{array}{c}1970-71 \text { to } \\
1979-80\end{array}$} & \multirow{2}{*}{ Population } & Linear & $\begin{array}{l}51.37 \\
6364 \\
\end{array}$ & $\begin{array}{c}1.34 \\
1818 \\
\end{array}$ & $\begin{array}{c}0.0122 \\
87 \\
\end{array}$ & 109.209 & 0.0000 & $\begin{array}{l}0.99 \\
925 \\
\end{array}$ & - \\
\hline & & Log- Linear & $\begin{array}{c}3.946 \\
532 \\
\end{array}$ & $\begin{array}{c}0.226 \\
11 \\
\end{array}$ & 8.1972 & 275.841 & 0.0000 & 0.99988 & 2.287 \\
\hline & \multirow{2}{*}{ Food Supply } & Linear & $\begin{array}{c}96.68 \\
7455\end{array}$ & $\begin{array}{l}2.29 \\
5727\end{array}$ & $\begin{array}{c}0.854 \\
999\end{array}$ & 2.685 & 0.0250 & $\begin{array}{c}0.44 \\
477\end{array}$ & - \\
\hline & & Log- Linear & $\begin{array}{c}4.578 \\
125\end{array}$ & $\begin{array}{c}0.020 \\
310\end{array}$ & $\begin{array}{c}0.007 \\
513\end{array}$ & 2.704 & 0.0243 & 0.44816 & 2.052 \\
\hline
\end{tabular}

Table 3, shows that in the decade from 1970-71 to 1979-80, the population had grown at an absolute rate of 1.34 crore per annum, whereas the food supply had grown at an absolute rate of 2.29 million ton per year. The semi log model shows that the values of slope of coefficient of population and food supply in the years 1970-71 to 1979-80 are 0.226 and 0.02 which shows that the population and food supply had grown at the rate of 22.61 and 2.03 per cent. The regression estimates are statistically significant at 5 per cent and 1 percent level. In the decade from 1970-71 to 1979-80, the population and food supply had increased at a compound growth rate of 2.287 and 2.052 per cent respectively. Thus, in the decade from 1970-71 to 1979-1980, the growth of food supply just over the growth of population.

Table 4: Growth of Population and Food Supply in the Decade from 1980-81 to 1989-90

\begin{tabular}{|c|c|c|c|c|c|c|c|c|c|}
\hline Period & Items & Model & $\mathbf{a}$ & b & Std-Error & T-Stab & Sig-t & $\mathbf{R}^{2}$ & CGR \\
\hline \multirow{4}{*}{$\begin{array}{l}1980-81 \\
1989-90\end{array}$} & \multirow{2}{*}{ Population } & Linear & $\begin{array}{l}66.02 \\
6667\end{array}$ & $\begin{array}{l}1.598 \\
788\end{array}$ & $\begin{array}{l}0.0163 \\
24\end{array}$ & 97.939 & 0.0000 & $\begin{array}{l}0.99 \\
917\end{array}$ & - \\
\hline & & Log-Linear & $\begin{array}{l}4.195 \\
586 \\
\end{array}$ & $\begin{array}{l}0.021 \\
384 \\
\end{array}$ & 7.1628 & 298.546 & 0.0000 & 0.99991 & 2.161 \\
\hline & \multirow{2}{*}{ Food Supply } & Linear & $\begin{array}{l}124.4 \\
9600\end{array}$ & $\begin{array}{l}4.009 \\
636\end{array}$ & $\begin{array}{l}1.008 \\
326\end{array}$ & 3.977 & 0.0041 & $\begin{array}{l}0.66 \\
405\end{array}$ & - \\
\hline & & Log- Linear & $\begin{array}{l}4.834 \\
501\end{array}$ & $\begin{array}{l}0.026 \\
969\end{array}$ & $\begin{array}{l}0.006 \\
687\end{array}$ & 4.033 & 0.0038 & 0.67028 & 2.734 \\
\hline
\end{tabular}

Source: Computer by the Researcher

The table 4 shows that in the decade from 1980-81 to 1981-90, the population had grown at an absolute rate of 1.58 crore per annum whereas, food supply had grown at an absolute rate of 4.00 million ton per year. The semi log model shows that the values of slope coefficient of population and food supply in the years 1980-81 to 1989-90 are 0.0213 and 0.0269 which shows that the population and food supply had grown at the rate of 2.14 and 2.7 per cent. The regression estimates are statistically at 5 per cent and 1 per cent level of significant. In the decade from 1980-81 to 1989-90 the population and food supply had increased at a compound growth rate of 2.16 and 2.734 per cent respectively. Thus, in the decade from 1980-81 to 1989-90, the growth rate of food supply is just more than the growth of population.

Table 5: Growth of Population and Food Supply in the Decade from 1990-91 to 1999-2000

\begin{tabular}{|c|c|c|c|c|c|c|c|c|c|}
\hline Period & Items & Model & $\mathbf{a}$ & $\mathbf{b}$ & $\begin{array}{l}\text { Std- } \\
\text { Error }\end{array}$ & T-Stab & Sig-t & $\mathbf{R}^{2}$ & CGR \\
\hline \multirow{2}{*}{$\begin{array}{l}1990-91 \text { to } \\
1999-2000\end{array}$} & \multirow[t]{2}{*}{ Population } & Linear & $\begin{array}{l}81.95 \\
3333\end{array}$ & $\begin{array}{c}1.810 \\
303\end{array}$ & $\begin{array}{c}0.009 \\
554\end{array}$ & 189.484 & 0.0000 & $\begin{array}{c}0.99 \\
978\end{array}$ & - \\
\hline & & Log- & 4.410 & 0.019 & 0.0001 & 137.526 & 0.0000 & 0.99958 & 1.992 \\
\hline
\end{tabular}




\begin{tabular}{|c|c|c|c|c|c|c|c|c|c|}
\hline & & Linear & & 725 & 43 & & & & \\
\cline { 2 - 9 } & \multirow{4}{*}{ Food } & Linear & $\begin{array}{c}166.9 \\
74667\end{array}$ & $\begin{array}{c}3.938 \\
970\end{array}$ & $\begin{array}{c}0.6368 \\
50\end{array}$ & 6.185 & 0.0003 & 0.82705 & - \\
\cline { 3 - 10 } & Supply & $\begin{array}{c}\text { Log- } \\
\text { Linear }\end{array}$ & 5.123165 & $\begin{array}{c}0.020 \\
818\end{array}$ & $\begin{array}{c}0.0034 \\
01\end{array}$ & 6.121 & 0.0003 & 0.82404 & 2.104 \\
\hline
\end{tabular}

From the above table 5, it is vivid clear that in the decade from 1990-91 to 1999-2000, the population had grown at an absolute rate of 1.81 crore per annum where as food supply had grown at an absolute rate of 3.938 million ton per year. The semi log model shows that the values of slope coefficient of population and food supply in the decade from 1990-91 to 1999-2000 are 0.019 and 0.020, which shows that the population and food supply had grown as the rate of 1.97 and 2.08 per cent. The regression estimates are statistically significant at 5 per cent and 1 per cent level.In the decade from 1990-91 to 1999-2000 the population and food supply had increased at a compound growth rate of 1.992 and 2.104 per cent, respectively. In this period also, the growth of food supply has just surpassed the growth of population.

Table 6: Growth of Population and Food Supply in the Decade from 1999-2000 to 2009-2010

\begin{tabular}{|c|c|c|c|c|c|c|c|c|c|}
\hline Period & Items & Model & $\mathbf{a}$ & b & $\begin{array}{l}\text { Std- } \\
\text { Error }\end{array}$ & T-Stab & Sig-t & $\mathbf{R}^{2}$ & CGR \\
\hline \multirow{4}{*}{$\begin{array}{c}1999-2000 \\
\text { to } 2009- \\
2010\end{array}$} & \multirow{2}{*}{ Population } & Linear & $\begin{array}{l}100.5 \\
46667\end{array}$ & $\begin{array}{l}1.65 \\
6970\end{array}$ & $\begin{array}{c}0.0153 \\
86\end{array}$ & 107.693 & 0.0000 & $\begin{array}{l}0.99 \\
931\end{array}$ & - \\
\hline & & $\begin{array}{l}\text { Log- } \\
\text { Linear }\end{array}$ & 4.613176 & $\begin{array}{c}0.015 \\
139 \\
\end{array}$ & $\begin{array}{c}0.000 \\
233 \\
\end{array}$ & 65.012 & 0.0000 & 0.99811 & 1.525 \\
\hline & \multirow{2}{*}{$\begin{array}{l}\text { Food } \\
\text { Supply }\end{array}$} & Linear & $\begin{array}{c}189.00 \\
4667 \\
\end{array}$ & $\begin{array}{c}3.912 \\
424 \\
\end{array}$ & $\begin{array}{c}1.4842 \\
43 \\
\end{array}$ & 2.636 & 0.0299 & $\begin{array}{c}0.46 \\
482 \\
\end{array}$ & - \\
\hline & & $\begin{array}{l}\text { Log- } \\
\text { Linear }\end{array}$ & 5.243100 & $\begin{array}{c}0.018 \\
782\end{array}$ & $\begin{array}{c}0.007 \\
401\end{array}$ & 2.538 & 0.0348 & 0.44597 & 1.896 \\
\hline
\end{tabular}

It is evident from Table 6 in the decade from 2000-01 to 2009-2010, the population growth at an absolute rate of 1.65 crore per annum whereas the food supply had grown at an absolute rate of 3.91 million ton per year. The semi log model shows that the value of slope coefficient of population and food supply in the decade from 2000-01 to 2009-10 are 0.015 and 0.018 , which shows that the population and food supply had grown at the rate of 1.5 and 1.9 per cent. The regression estimates are statistically significant at 5 per cent and 1 per cent level. In the decade from 2000-01 to 2009-10, the population and food supply had increased at a compound growth rate of 1.525 and 1.896 per cent, respectively.

Table 7: Growth of Population and Food Supply in the decade from 2010-11 to 2017-2018

\begin{tabular}{|c|c|c|c|c|c|c|c|c|c|}
\hline Period & Items & Model & $\mathbf{a}$ & B & $\begin{array}{c}\text { Std- } \\
\text { Error }\end{array}$ & $\begin{array}{c}\text { T- } \\
\text { Stab }\end{array}$ & Sig-t & $\mathbf{R}^{2}$ & CGR \\
\hline \multirow{4}{*}{$\begin{array}{c}2010-11 \\
\text { to } 2017- \\
2018\end{array}$} & \multirow{2}{*}{ Population } & Linear & $\begin{array}{l}117.8 \\
4286\end{array}$ & $\begin{array}{c}1.744 \\
048\end{array}$ & $\begin{array}{c}0.083 \\
506\end{array}$ & 20.885 & 0.0000 & 0.98643 & - \\
\hline & & $\begin{array}{l}\text { Log- } \\
\text { Linear }\end{array}$ & 4.770863 & $\begin{array}{c}0.013 \\
915\end{array}$ & $\begin{array}{c}0.000 \\
745\end{array}$ & 18.690 & 0.0000 & 0.98311 & 1.401 \\
\hline & \multirow{2}{*}{$\begin{array}{l}\text { Food } \\
\text { Supply }\end{array}$} & Linear & $\begin{array}{l}243.4 \\
11071\end{array}$ & $\begin{array}{l}3.94 \\
9762\end{array}$ & $\begin{array}{c}1.527 \\
303\end{array}$ & 2.586 & 0.0414 & 0.52711 & - \\
\hline & & $\begin{array}{l}\text { Log- } \\
\text { Linear }\end{array}$ & 5.497189 & $\begin{array}{c}0.014 \\
871\end{array}$ & $\begin{array}{c}0.005 \\
797\end{array}$ & 2.565 & 0.0426 & 0.52309 & 1.498 \\
\hline
\end{tabular}

Table 7 shows that in the decade from 2010-11 to 2017-2018, the population had grown at an absolute rate of 1.74 crore per annum, whereas, food supply had grown at an absolute rate of 3.94 million ton per year. The semi log model shows that the values of slope coefficient of population and food supply for the period from 2010-11 to 2017-18 are 0.013 and 0.014, which shows that the population and supply had grown at the rate of 1.4 and 1.5 per cent. The regression estimates are statistically at 5 per cent and 1 per cent level of significant. In the decade from 2010-11 to 2017-18, the 
population and food supply had increased at a compound growth rate of 1.401 and 1.498 per cent respectively. Thus, in the decade from 2010-11 to 2017-18, the growth rate of food supply is just over the growth of population.

Table 8: Growth of Population and Food Supply in the Decade from 1960-61 to 2017-2018

\begin{tabular}{|c|c|c|c|c|c|c|c|c|c|}
\hline Period & Items & Model & $\mathbf{A}$ & B & $\begin{array}{l}\text { Std- } \\
\text { Error }\end{array}$ & T-Stab & Sig-t & $\mathbf{R} 2$ & CGR \\
\hline \multirow{4}{*}{$\begin{array}{l}1960-61 \\
\text { to } 2017- \\
2018\end{array}$} & \multirow{2}{*}{ Population } & Linear & $\begin{array}{r}36.51 \\
6152\end{array}$ & $\begin{array}{c}1.597 \\
173\end{array}$ & $\begin{array}{c}0.016 \\
250\end{array}$ & 98.289 & 0.0000 & $\begin{array}{l}0.99 \\
424\end{array}$ & - \\
\hline & & $\begin{array}{c}\text { Log- } \\
\text { Linear }\end{array}$ & $\begin{array}{c}3.784 \\
620\end{array}$ & $\begin{array}{c}0.019 \\
920\end{array}$ & $\begin{array}{c}0.000 \\
192\end{array}$ & 103.819 & 0.0000 & 0.99483 & 2.012 \\
\hline & \multirow{2}{*}{$\begin{array}{l}\text { Food } \\
\text { Supply }\end{array}$} & Linear & $\begin{array}{l}60.85 \\
9056 \\
\end{array}$ & $\begin{array}{c}3.496 \\
414\end{array}$ & $\begin{array}{c}0.087 \\
307\end{array}$ & 40.047 & 0.0000 & 0.96626 & 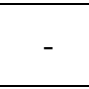 \\
\hline & & $\begin{array}{l}\text { Log- } \\
\text { Linear }\end{array}$ & $\begin{array}{c}4.360 \\
510\end{array}$ & $\begin{array}{c}0.022 \\
646\end{array}$ & $\begin{array}{c}0.000 \\
614\end{array}$ & 36.878 & 0.0000 & 0.96045 & 2.290 \\
\hline
\end{tabular}

Source: Computer by the Researcher

In the whole period from 1960-61 to 2017-18, the population had grown at an absolute rate of 1.59 crore per annum, whereas the food supply had grown at an absolute rate of 3.49 million ton per year. The semi log model shows that the values of slope coefficient of population and food supply in the whole period from 1960-61 to 2017-18 are 0.019 and 0.022 , which shows that the population and food supply had grown at the rate of 1.99 and 2.26 per cent. The regression estimates are statistically significant at 5 per cent and 1 percent level. In the whole period from 1960-61 to 2017-18, the population and food supply had increased at a compound growth rate of 2.012 and 2.290 per cent, respectively. Thus, the study clearly shows that for the whole period the compound growth rate of food supply and population are almost equal.

\section{CONCLUSIONS}

In India, the changes in agricultural production due to Green Revolution, agribusiness, fertilizers, pesticides and now more recently agri tourism have really undercut the Malthus thesis, which was written well before any of the aforementioned technologies existed. Sustainable development is a concept which is an outcome of the deterministic approach, which Malthus uses in that time frame control on human greed by the ethical value is good indication of Malthusian theory, which is still valid in the context. In conclude, Malthus theory is not fully functioning in present context.

\section{REFERENCES}

1. Ian Bower (1964), Population, Cambridge University Press, pp 81-121.

2. Ronald Freedman (1971), Population: The Vital Revolution, Higginbothams (P) Ltd., Madras, pp-149-165.

3. Charles Gide, Charles Rist and Richard (1973),A History of Economic Doctrines, Oxford University Press, Calcutta, pp 135153.

4. Jaipal P Ambannavar (1975), Second India Studies population, The Macmillan Company of India Limited, Bombay, pp 27-40.

5. Umesh, K. S., V. K. Pravin, and K. Rajagopal. "Experimental Investigation and CFD Analysis of Multi-Cylinder Four Stroke SI Engine Exhaust Manifold for Optimal Geometry to Reduce Back Pressure and to Improve Fuel Efficiency." International Journal of Automobile Engineering Research and Development, 4, 1320 (2014).

6. Alam K (1978), “The Population Theory of Malthus - A Study of Its Relevance”, Indian Economic Journal, Vol.26, No.1, pp 233-34.

7. David M. Heer (1978), Society and Population, Prentice Hall of India Private Limited, New Delhi pp 111-118.

8. Singh S.P \& Jain S.K. (1978), Relevance of Malthus to the Population Problem of India”, The Indian Economic Journal, Vol. 
26, No. 4, pp 213 to 224 .

9. Irfan, Osama Mohamed. "Influence of Specimen Geometry and Lubrication Conditions on the Compressionbehavior of Aa6066 Aluminum Alloy." International Journal of Mechanical Engineering (Ijme) 5.1, Dec -Jan 2015, 14-24

10. Sundaram K.P.M and Vaish M.C (1978) Principles of Economics, Vikas Publishing house Pvt. Ltd, New Delhi, pp $254-263$.

11. Abdel-All, Nassar H., et al. "Geometric image edge detection techniques." Int. J. Math. Comput. Applics. Res 3 (2013): 1-14.

12. Planning Commission (1985), The Seventh Five Year Plan: 1985-90, Vol.1, New Delhi, pp 10-12.

13. Asha A Bhende and Jara Kanitkar (1994), Principles of Population Studies, Himalaya Publishing House, Delhi, pp 87-104.

14. Hans Raj (1995), Fundamentals of Demography, Surjeet Publications, Delhi,pp 140-151.

15. Al-Ethary, Adnan Dawood M., And Adel Salam K. Al-Hashimi. "The Impact Prices and Some Factors on Maize Production in Wasit Governorate-An Econometrics Study." International Journal of Applied and Natural Sciences (Ijans) 3.3, May 2014, $101-112$

16. Ron Moore and Jan Ryan (1995), Sustainable Development: Policy and Practice, New Age International (P) Limited, Publishers, Bangkok, pp 147-161.

17. Das M.M and Datta L (2006), Growth of Population and Food Production in North East India, Geographical Review of India, Vol. 68 Issue 1, pp 81-88.

18. Maria John Kennedy and Veluchamy V. (2011), An Assessment of Malthusian Theory of Population in Indian Scenario, Indian Streams Research Journal, Vol. I, Issue II, pp 73-78. 